\title{
EXPERIENCE WITH EARLY ANTERIOR OPERATION IN ACUTE INJURIES OF THE CERVICAL SPINE
}

\author{
By W. J. Horsey, M.D., F.R.C.S.(C), F.A.C.S., ${ }^{1}$ W. S. TuCKer, M.D., F.R.C.S.(C), ${ }^{1}$ \\ A. R. Hudson, M.B., F.R.C.S.(Ed)(C), ${ }^{1}$ and S. W. SchatZ, M.D., F.R.C.S.(C) ${ }^{2}$ \\ ${ }^{1}$ Division of Neurosurgery, Department of Surgery, St Michael's Hospital and the University \\ of Toronto, Toronto; and ${ }^{2} \mathrm{HGH}$ MacMaster Clinic, Hamilton, Ontario, Canada
}

Abstract. Of Ior patients with acute injury to the cervical spine below the level of the axis, 74 were selected for anterior operation to ensure stability and comfort and to decompress the neural elements when indicated. Forty-six of the patients underwent a Cloward fusion at the level of the injury. Twenty-eight were treated by bar graft fusion. The indications for these procedures and the techniques involved are outlined. A successful operative result was achieved primarily in 65 of the 74 patients and eventually in 73 patients. The management mortality for patients treated by anterior operation was $2 \cdot 7$ per cent. The advantages of these procedures are the achievement of comfort, the facilitation of early rehabilitation, the maintenance of bony alignment and the preservation and maximal recovery of neurological function.

Key words: Anterior fusion; bar graft fusion.

\section{Introduction}

THE indications for surgical intervention in the care of patients with acute cervical injuries remain controversial. Some enthusiastic authors recommend early operation in most cases (Cloward, I96I; Evans, I96I; Norrell \& Wilson, I970; Ransohoff \& Sadik, I972; Verbiest, I973). Others follow a more moderate course, advising surgical treatment in selected instances (Beatson, 1963; Cheshire, 1970; Holdsworth, 1963; Jacobs, 1975; Nieminen, I973, 1974; Raynor, 1968; Rogers, I957; Stauffer \& Kaufer, I975). A number hold the view that surgery is almost never justified (Burke \& Berryman, I971; Clawson et al., I971; Guttmann, I965, 1976. At present, most believe that decompressive laminectomy alone has no merit (Beatson, I963; Holdsworth, I963; Braakman \& Penning, 1973; Verbiest, I973; Guttmann, 1976), for it does not improve cord function and may render the spine less stable and at the same time remove the bony structures needed for a posterior fusion should this be required.

The posterior approach to the cervical spine offers the best access for open reduction, but posterior fusion does not allow good internal fixation, although an excellent fusion may eventually be obtained.

The anterior operation favours the removal of bone or disc fragments which almost invariably compress the neural elements on their anterior aspect. It permits effective internal fixation and excellent stability. Readily accomplished, it promotes comfort and safe early mobilisation of the patient. Its disadvantage is that it does not provide for easy open reduction and preferably, closed reduction is achieved prior to anterior decompression and fusion. There has been an emphasis on anterior approach to cervical injuries at St Michael's Hospital when it has been deemed that stabilisation of the spine or decompression of the spinal cord or nerve roots is needed. 


\section{Materials and Methods}

Between I96I and I974, IOI patients with injuries to the cervical spine were treated on the Neurosurgical Service at St Michael's Hospital. Seventy-four of these were selected for an anterior cervical operation. All of them were followed for more than a year. During the period of this review, a team approach to the care of patients with cord lesions has evolved. There is co-ordinated participation by designated members of the urological, plastic surgical and rehabilitation services, all of whose efforts contribute to the quality of life of the injured.

The ages of the patients ranged from I 5 to 77 years. Eighty-seven were male and 14 female. Forty-six were injured in or near Toronto. Fifty-five were transferred from distant areas after initial assessment at another hospital where skull calliper or halter traction had usually been applied.

Motor vehicle accidents were responsible for about one-half of the injuries. Falls and various sporting accidents, especially diving into shallow water, accounted for most of the others (Table I). Intoxication with alcohol, and in one case with LSD, played a role in at least 12 instances.

Thirty-one of the IOI patients had associated head injuries. These varied from mild concussions in most to major contusions and intracranial haemorrhages in a few. The latter contributed to a fatal outcome or resulted in such cerebral deficits that rehabilitation was difficult or impossible. Concurrent injuries to the chest and limbs were less frequent and were not studied in detail.

The neurological status on arrival at hospital is depicted in Table II. Thirtyone of the IOI patients had a spinal cord deficit judged complete by clinical criteria from the time of injury. In none of these was there significant recovery of function

\section{TABLE I}

Type of trauma: Ior acute cervical spinal injuries

\begin{tabular}{lr}
\hline \multicolumn{1}{c}{ Type of trauma } & $\begin{array}{c}\text { No. of } \\
\text { cases }\end{array}$ \\
\hline Motor vehicle accidents & 49 \\
Falls & 27 \\
Diving & 8 \\
Other sports & 8 \\
Industrial accidents & 7 \\
Miscellaneous & 2 \\
\hline
\end{tabular}

TABLE II

Initial neurological deficit

\begin{tabular}{lcc}
\hline \multicolumn{1}{c}{ Deficit } & $\begin{array}{c}\text { Total } \\
\text { No. }\end{array}$ & $\begin{array}{c}\text { Anterior } \\
\text { operation }\end{array}$ \\
None & I9 & I4 \\
Root only & I3 & 9 \\
Incomplete cord lesion & 38 & 30 \\
Complete cord lesion & $3 \mathrm{I}$ & $2 \mathrm{I}$ \\
\hline
\end{tabular}


of the cord during the entire period of observation of at least I year. The goal in the initial surgical management was to obtain solid internal fixation in good bony alignment, permitting comfort and early rehabilitation. Furthermore, decompression at the level of injury may have promoted recovery of important nerve root function. This followed operation in nine of 2 I patients with complete cord lesions who underwent an anterior operation. The recently developed but unproven methods proposed for the early treatment of traumatic paraplegia were not used (e.g. cord cooling, irrigation, hyperbaric oxygen, catecholamine inhibitors). In recent years steroids have been employed without demonstrable effect.

Most patients did not suffer complete cord lesions; about one-third had no neurological deficit or only root interference while the remainder had partial cord impairment. In these, the aims of surgical management were extended to include the facilitation of recovery by decompression and the prevention of loss of neural function by stabilisation. None who were subjected to operation showed evidence of worsening following the procedure and almost all improved. Despite the knowledge that restoration of root function and recovery of incomplete cord lesions are common after other methods of management, the high incidence of improvement remained gratifying.

It is difficult to evaluate accurately the results of operation. One has the impression that most statements in this regard are anecdotal. The neurological changes following the procedures are noted in Table III.

Of the IOI cases of acute injury to the cervical spine, 27 were not treated by the anterior operation for the following reasons:

(a) Six were fused by a posterior approach, in three of which attempts at closed reduction had failed to restore the bony alignment.

(b) Six of nine patients with central cord damage due to forced hyperextension of the spondylotic spine were not subjected to operation because of advanced age, the presence of a complete cord lesion, multiple level inyolvement, or the known ineffectiveness of any procedure in most of such cases.

(c) Five died without operation, three of associated injuries and two of the direct consequences of cord trauma.

(d) Five had minor stable vertebral injuries such as avulsion of a spinous process.

(e) Three were so critically injured that their survival was in doubt because of head and chest trauma. These were managed conservatively.

\section{TABLE III}

Neurologic change with anterior fusion

\begin{tabular}{llcccc}
\hline \multicolumn{1}{c}{ Original } & $\begin{array}{l}\text { Result } \\
\text { deficit }\end{array}$ & No change & Improved & Worse & $\begin{array}{c}\text { Insufficient } \\
\text { information }\end{array}$ \\
\hline None & & I 4 & - & - & - \\
Root only & Cord & I & 7 & - & I \\
Incomplete & Root & 2 & 29 & - & - \\
Complete & Cord & I 8 & 6 & - & 22 \\
& Root & I & 9 & - & I I \\
\hline
\end{tabular}

* Patchy, incomplete sensory return only. 
(f) One had haemophilia.

(g) One was referred 3 months after injury with solid malunion of an unreduced fracture-dislocation.

Patients with acute injuries to the cervical spine below the axis, including dislocations, fracture-dislocations and burst fractures, were considered unstable and suitable for an anterior operation (Table IV). Whenever other injuires were accompanied by neurological damage, they were considered to be unstable or potentially so. In cases with questionable stability, we have tended to operate and we did not routinely employ flexion and extension radiographs unless the routine $\mathrm{X}$-rays were normal. More recently, lateral tomography has been effective in recognising obscure fractures. Failure to achieve alignment and stability by nonoperative treatment is common and may lead to pain or progressive neurological deficit (Beatson, I963; Cloward, I96I; Verbiest, 1973). Many reported series include patients who have been treated conservatively while harbouring doubtful or apparently minor lesions and who present subsequently with evidence of symptomatic instability (Kessler, I973; Rogers, I957; Verbiest, I973). The frequent findings at operation of severe disc damage and unsuspected looseness of the disrupted segments strengthen the argument for fusion. As will be shown, the low morbidity of the anterior operation and the advantages of early mobilisation of the operated patient justify an aggressive policy.

Anterior decompression and fusion were used in two cases of cervical cord deficit consequent upon acute central disc prolapse and in three instances of injury to the cord by forced hyperextension of a spondylotic spine. In the latter, the goals were to remove the cause of anterior cord compression and to halt movement at the offending segments. Surgery was performed only in the presence of a large central encroachment on the oil column at myelography.

The 74 patients who had an anterior procedure underwent the operation on an average 9.I days after injury or $7 \cdot 4$ days after admission to hospital. In more recent years, the operation has been done sooner. Delay was attributable to management priorities determined by associated injuries, to the timing of transfer from distant centres and to the interval required for reduction of fractures and dislocations.

\section{TABLE IV}

Management of various types of cervical spinal injury

\begin{tabular}{lcccc}
\hline \multicolumn{1}{c}{ Type of injury } & $\begin{array}{c}\text { Total } \\
\text { no. of cases }\end{array}$ & \multicolumn{2}{c}{ Anterior operation } \\
\cline { 3 - 5 } & & Cloward & Bar graft \\
\hline Burst fracture & 22 & 4 & I0 \\
Fracture-dislocation & 56 & 25 & I8 \\
Dislocation & I2 & I2 & - \\
Acute disc herniation & 2 & 2 & - \\
Hyperextension with spondylosis & 9 & 3 & - \\
Total cases & IOI & 46 & 28 \\
\cline { 3 - 5 } & & \multicolumn{3}{c}{74} \\
\hline
\end{tabular}


Restoration of the bony alignment by closed means was attempted before embarking on anterior procedures which offer unfavourable access for open reduction. A period of traction through skull callipers was often successful, but if it failed, the cervical spine was manipulated under general anaesthesia with muscle relaxants, monitored by fluoroscopy with image intensification. Our experience confirms the assertions of Burke and Berryman (1970), Evans (196I), and Stauffer and Kaufer (1975) that this method is safe. Of the 74 injuries treated by anterior fusion 30 did not require reduction. Twenty-four were re-aligned by skull traction in bed. Twenty-one had their fractures and dislocations manipulated under general anaesthesia and of these, I 5 were easily reduced while none were worsened neurologically. In one case with a complete cord lesion, accurate reduction was not accomplished and the mildly deformed position was accepted for fusion. In three, open posterior reduction preceded anterior fusion but it is perhaps significant that precise repositioning was not achieved in these cases which occurred early in our experience (Table V).

The remaining case was a 47-year-old man, the level of whose complete lesion was noted to be ascending on the 4th hospital day during skull traction which did not result in reduction of his $\mathrm{C}_{5}-6$ dislocation. The maximum weight applied was $32 \mathrm{lb}$. Manipulation under general anaesthesia was effective and an anterior fusion followed immediately. He continued to deteriorate and died of respiratory failure 2 days post-operatively. Unfortunately, a post-mortem examination was not obtained and the cause of his ascending myelopathy remains obscure. This is the only patient whose neurological status deteriorated during early management.

When the bony alignment was satisfactory, operation was performed provided that the patient's condition, particularly the respiratory status, was acceptable. The choice of the Cloward technique (Cloward, I96I) or the bar graft method was based on a study of the radiographs and on the appearance of the exposed spine at operation. Additional information was sometimes gained by intra-operative discography or a saline acceptance test. The Cloward technique was performed in 46 cases and the bar graft in 28 . With each method the spine was exposed through a small anterior skin crease incision in the neck just to the right of the midline. No matter how obvious the site of the lesion, radiographic confirmation of the level and of the reduction was obtained. In the Cloward technique, used when the integrity of vertebral bodies at the level of the lesion was sufficient to accept the dowel, a single disc was excised and a hole drilled to the depth of the posterior

\section{TABLE V}

Technique of reduction in 74 cases of cervical spine injury operated by the anterior approach

\begin{tabular}{ll}
\hline No reduction required & 30 cases \\
Skull traction only & 24 cases \\
Manipulation under G/A & 2I cases \\
& I5 reduced without incident \\
& I reduced-continued to deteriorate \\
& 5 failed \\
& I accepted \\
& I reduced with tongs \\
& 3 posterior operations \\
Posterior open reduction & 3 cases \\
\hline
\end{tabular}


cortex with the guard astride the intervertebral disc. Subsequently, an autogenous oversized dowel from the iliac crest was tapped into the hole while traction was applied to the skull tongs by the anaesthetist. When a vertebral body was comminuted, it was largely excised along with the discs above and below and the adjacent normal vertebral bodies were undercut with a high-speed air-driven burr. A block of bone fashioned from the iliac crest was manoeuvred into place. In both methods, prior to the insertion of the graft, the dura was exposed and loose fragments of bone and disc material removed from the spinal canal centrally and laterally to decompress the neural structures. Frequently a metal staple was used to decrease the likelihood of slippage of the graft. Skull tongs were usually discarded soon after the operation thereby minimising the risks of the prolonged use of callipers (Drake, I962; Schneider, I957).

\section{Case Reports}

The following brief case reports illustrate the typical courses of patients in this series.

Case I. D. L., a I6-year-old male, was rendered completely quadriplegic in a motor vehicle accident in which he sustained a fracture-dislocation of C6-7. The 6th cervical vertebra was displaced forward on the 7 th; there was a flake fracture of the anterior superior aspect of the 7 th cervical vertebral body. Calliper traction was established before his transfer from another city and reduction was achieved. Four days after injury, a Cloward fusion was performed at C6-7. The graft was eccentrically placed, more bone being drilled from the damaged superior part of the 7 th cervical vertebral body than from the intact 6th vertebra. A metal staple from the graft to the 7 th cervical vertebral body prevented anterior displacement of the graft. On the $13^{\text {th }}$ post-operative day, the patient was sitting, wearing a Forrester brace. A week later, he was transferred to the Rehabilitation Unit where his primary rehabilitation to life as a quadriplegic was completed in IOI days. He was discharged home in a wheelchair to continue his high-school education.

Case 2. B. G., a 23-year-old male, sustained a fracture-dislocation at C6-7 with a unilateral 7 th cervical root deficit (Fig. Ia). The 7 th cervical vertebral body was compressed and a wedge of bone displaced from its anterior superior aspect. Radiographs obtained elsewhere revealed excessive separation of the spinous processes of $\mathrm{C}_{6}$ and $\mathrm{C}_{7}$ with flexion. No reduction was necessary. The 7 th cervical root was decompressed on the left by removing extruded disc material and a Cloward fusion performed. A staple was inserted between the body of the 6th cervical vertebra and the $\mathrm{C}_{7}-\mathrm{T}_{1}$ disc space to prevent anterior extrusion of the graft. The patient was discharged to his home I 9 days after operation wearing a four-poster brace. His root dysfunction recovered. The patient returned to work with no complaints referable to his injury. A radiograph taken I year later showed a solid fusion in good alignment (Fig. Ib).

Case 3. J. B., an I8-year-old male, fell a distance of about $20 \mathrm{ft}$., sustaining a mild concussion and a burst fracture of his 5 th cervical vertebra (Fig. 2a). He had an incomplete spinal cord lesion. The power of elbow flexion and shoulder abduction was excellent. Elbow extension and wrist extension were weak on the left and absent on the right. There was no power of wrist flexion, of grip or of movements subserved by the intrinsic muscles of the hands. Respiration was diaphragmatic. There was no voluntary power in the lower limbs.

There was analgesia below the 6th cervical segment bilaterally. There was gross impairment of posterior column sensation in the lower limbs. The biceps and brachioradialis reflexes were normal. The triceps reflexes were absent. The knee and ankle jerks were present and quite brisk. The abdominal reflexes were absent and the plantar responses extensor. He required an indwelling catheter. 

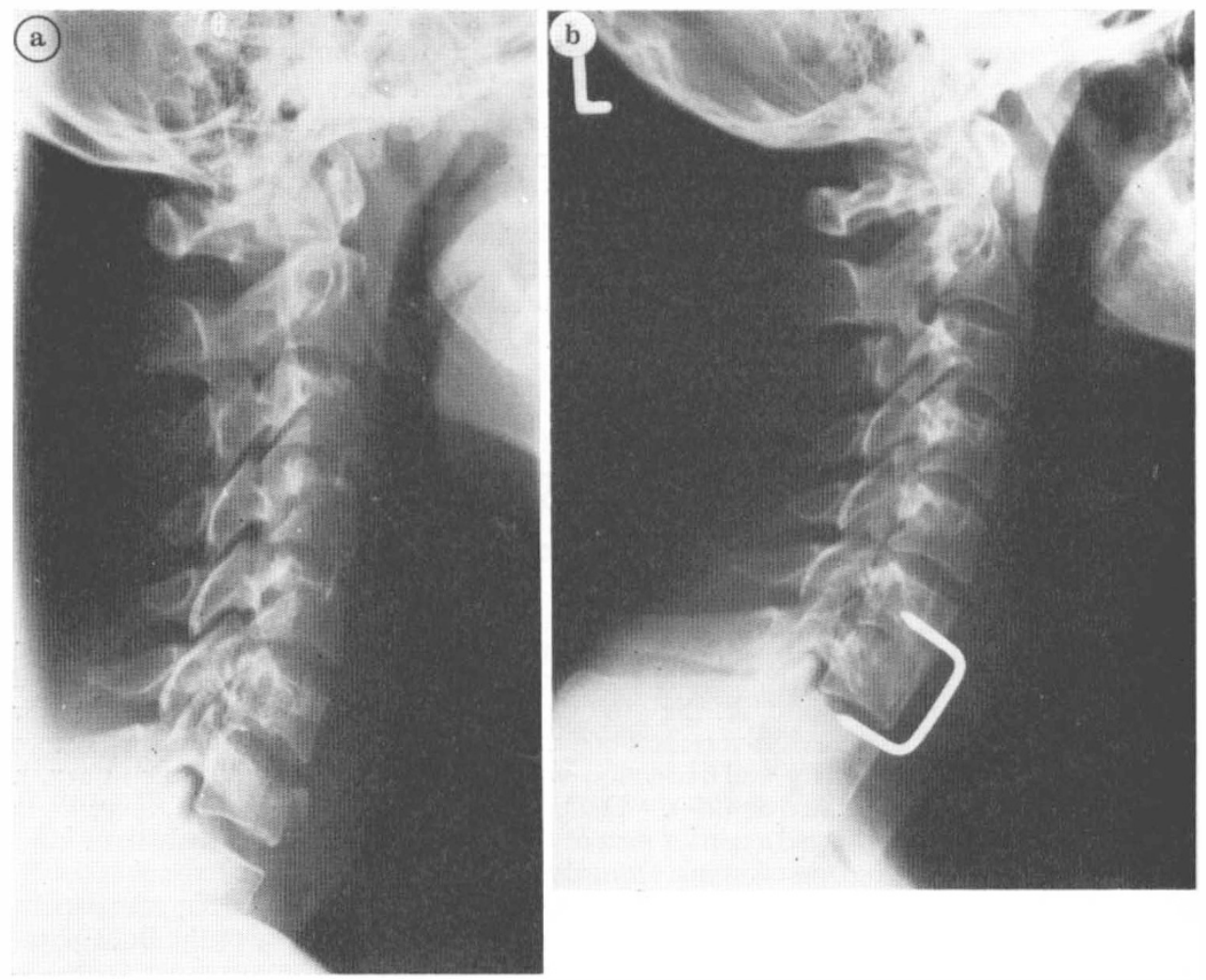

FIG. I

Case 2. (a) Lateral radiograph of the cervical spine shortly after injury;

(b) same, I year later (Cloward fusion).

In calliper traction his neurological status improved and weak movement returned to the lower limbs. Six days after injury he underwent an anterior interbody fusion by the bar graft technique from the 4 th to the 6 th cervical vertebrae. The neurological status improved slowly. On the 3oth day, he was transferred to the Rehabilitation Unit where he was rapidly mobilised. His rehabilitation programme was completed and he was discharged as a quadriparetic still improving on the 84th hospital day. He returned to the hospital on numerous occasions for follow-up examinations. One and one-half years after injury, he had good power in all muscle groups of his upper and lower limbs, although he was quite spastic on the left. There was spino-thalamic sensory loss on the right. Despite frequency, he had good control of his urinary bladder. He complained of impotence. He had just completed a course in welding and was employed. A lateral $\mathrm{X}$-ray of his cervical spine revealed incorporation of his graft in acceptable position. Anterior osteophytes had appeared below the fusion (Fig. $2 b$ ).

\section{Results}

Early anterior stabilisation of the spine facilitated mobilisation and rehabilitation. Patients undergoing a Cloward type of fusion were allowed up on an average of 13.9 days post-operatively, while those receiving bar grafts averaged 2 I. 5 days of complete bed rest. The patients wore a Forrester four-poster brace for at least 2 

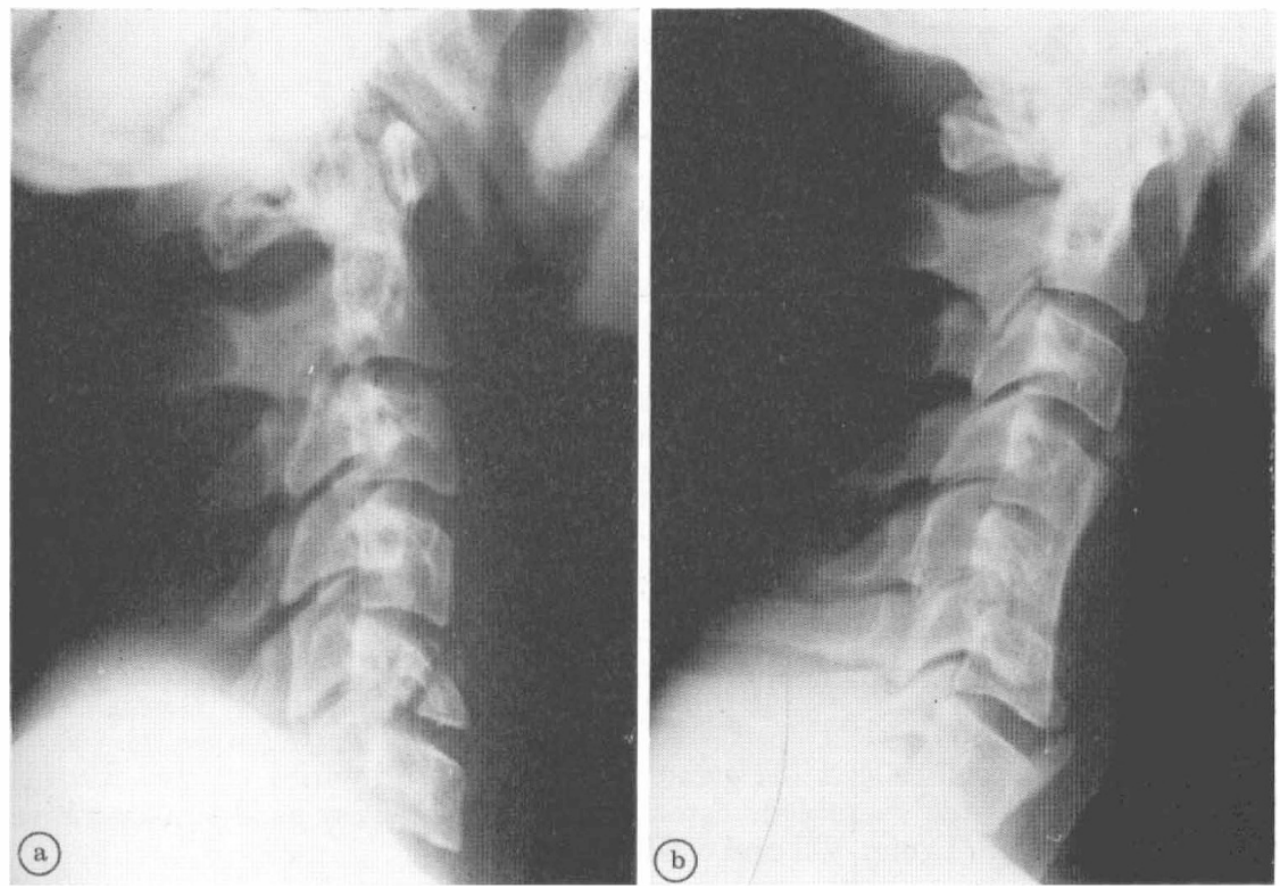

FIG. 2

Case 3. (a) Lateral radiograph of the cervical spine shortly after injury;

(b) same, I year later (bar graft fusion).

months until clinical and stress radiographic evidence of bony healing indicated that it was safe to discard external support. As soon as the patient was up (and often while still in bed) the rehabilitation programme was begun with early transfer to the rehabilitation unit. The average time required for primary rehabilitation of cord-injured patients was 93 days. This compares favourably with other centres in Ontario where the length of stay is considerably longer (Botterell et al., I975). Patients were discharged home but they were followed closely and often encouraged to attend out-patients clinics. Rarely, they were transferred to hospital for the chronically ill if independence at home was considered impossible for a variety of social or medical reasons.

Most of the 74 patients progressed uneventfully to solid union after a single operation and there were no cases of pseudarthrosis at the time of review at least I year after injury. Four complained of mild neck discomfort aggravated by prolonged periods in the erect posture (Table VI).

Forty-two of the 46 Cloward procedures and 23 of the 28 bar graft operations were acceptable primarily. Nine of the satisfactory cases showed some minor angulation, deformity or imperfect position of the graft considered insufficiently severe to warrant revision. In eight cases, further surgery was deemed necessary to correct a major degree of deformity or displacement of the graft. This was done in seven instances at a second procedure carried out on an average 28 days after the primary operation. None of these patients suffered neurological worsening. The eighth patient died of a gastrointestinal haemorrhage presumably due to stress ulceration I 5 days after operation. The slightly higher incidence of difficulty with I $5 / 2-B$ 


\section{TABLE VI}

Anterior fusion cases

\begin{tabular}{|c|c|c|}
\hline \multirow[t]{2}{*}{ Result } & \multicolumn{2}{|c|}{ Procedure } \\
\hline & Cloward & Bar graft \\
\hline $\begin{array}{l}\text { Completely satisfactory } \\
\text { fusion primarily } \\
\text { Satisfactory fusion primarily, }\end{array}$ & 37 & I9 \\
\hline $\begin{array}{l}\text { some X-ray abnormality } \\
\text { Total satisfactory fusions }\end{array}$ & 5 & 4 \\
\hline $\begin{array}{l}\text { Total satisfactory fusions } \\
\text { Unsatisfactory requiring }\end{array}$ & 42 & 23 \\
\hline further surgery & 4 & $5^{\star}$ \\
\hline Total & 46 & 28 \\
\hline
\end{tabular}

the bar graft method reflects the greater severity of the injuries selected for this type of treatment and the problems associated with maintaining good post-operative skeletal alignment (Tables VII and VIII).

The results with respect to the neurological aspects have been described (Table III). There were no significant decubitus ulcers in the series of operated patients during the hospitalisation, although three complete quadriplegics had small areas of superficial ulceration which healed rapidly with dressings alone.

The mortality in this series is low and differs little from that in other reports (Botterell et al., 1975; Hardy, 1976). Among the IOI patients, there were seven deaths during the initial period of hospital stay (Table IX). Five of those not

\section{TABLE VII}

Unsatisfactory results: Cloward fusion (4)

\begin{tabular}{|c|c|c|}
\hline Complication & $\begin{array}{l}\text { Contributing } \\
\text { factors }\end{array}$ & Management \\
\hline $\begin{array}{l}\text { I. C7 root pain persisted after } \\
\text { C5-6 fusion for } \text { C5- } 6 \text { fracture- } \\
\text { dislocation }\end{array}$ & $\begin{array}{l}\text { Nil. } \\
\text { C6-7 discogram at } \\
\text { first operation was } \\
\text { normal }\end{array}$ & $\begin{array}{l}\text { Myelogram showed } \mathrm{C}_{7} \text { root } \\
\text { compression. Cloward at } \\
\text { C6-7 relieved pain }\end{array}$ \\
\hline $\begin{array}{l}\text { 2. } \mathrm{C}_{5}-6 \text { fusion in error for } \mathrm{C}_{4}-5 \\
\text { fracture-dislocation }\end{array}$ & $\begin{array}{l}\text { No intra-operation } \\
\text { X-ray }\end{array}$ & $\mathrm{C}_{4-5}$ fusion same day \\
\hline $\begin{array}{l}\text { 3. Graft extruded anteriorly } \\
\text { after C6-7 fusion for fracture- } \\
\text { dislocation }\end{array}$ & No staple used & $\begin{array}{l}\text { Graft replaced and staple } \\
\text { added }\end{array}$ \\
\hline $\begin{array}{l}\text { 4. Graft extruded anteriorly } \\
\text { with recurrent subluxation } \\
\text { after } \mathrm{C} 5-6 \text { fusion for fracture- } \\
\text { dislocation }\end{array}$ & $?$ & $\begin{array}{l}\text { Replaced and re-extruded. } \\
\text { Posterior wiring and bone } \\
\text { graft at third operation }\end{array}$ \\
\hline
\end{tabular}




\section{TABLE VIII}

Unsatisfactory results: bar graft fusion (5)

\begin{tabular}{|c|c|c|}
\hline Complications & $\begin{array}{l}\text { Contributing } \\
\text { factors }\end{array}$ & Management \\
\hline $\begin{array}{l}\text { I. } \mathrm{C}_{4}-6 \text { graft for } \mathrm{C}_{5}-6 \text { fracture- } \\
\text { dislocation extruded } \\
\text { anteriorly }\end{array}$ & Poorly fitting graft & $\begin{array}{l}\text { Bed for graft improved: graft } \\
\text { replaced }\end{array}$ \\
\hline 2. Same as above & $\begin{array}{l}\text { No immobilisation } \\
\text { post-operatively }\end{array}$ & New graft \\
\hline $\begin{array}{l}\text { 3. Anterior extrusion of } \mathrm{C}_{5-7} \\
\text { graft for fracture-dislocation }\end{array}$ & $\begin{array}{l}\text { ? ? Comminution of } \\
\text { C5 body ? ? }\end{array}$ & $\begin{array}{l}\text { Patient died of G.I. bleeding } \\
\text { before re-operation }\end{array}$ \\
\hline $\begin{array}{l}\text { 4. C5-7 graft for } \mathrm{C}_{5-6} \text { fracture- } \\
\text { dislocation. Staple } \\
\text { extruded and C5 slipped } \\
\text { anteriorly }\end{array}$ & $\begin{array}{l}\text { Traumatic anterior } \\
\text { meningocoele }\end{array}$ & Posterior fusion \\
\hline $\begin{array}{l}\text { 5. C6-TI graft for burst } \\
\text { fracture C7. Some collapse } \\
\text { of graft, with C8 radicular } \\
\text { pain }\end{array}$ & $\begin{array}{l}\text { Mobilised very early } \\
\quad \text { ( } 5 \text { days })\end{array}$ & $\begin{array}{l}\text { Posterior wiring. Arrested } \\
\text { collapse and relieved } \\
\text { pain }\end{array}$ \\
\hline
\end{tabular}

TABLE IX

Management mortality: IOI cases of cervical spinal injury

\begin{tabular}{lcc}
\hline \multicolumn{1}{c}{ Management } & \multicolumn{2}{c}{ Cause of death } \\
\cline { 2 - 3 } \cline { 3 - 3 } & Associated injuries & Cervical injury only \\
\hline Anterior fusion & - & $2^{\star}$ \\
No fusion performed & 3 & 2 \\
\hline
\end{tabular}

* One of these patients died of massive gastrointestinal haemorrhage 15 days after speration.

selected for operation died, three with multiple injuries and two as a direct consequence of the spinal trauma. Two of the 74 patients selected for anterior fusion died, one from massive gastrointestinal haemorrhage and one from respiratory paralysis (vide supra).

The overall mortality for patients with spinal cord involvement (69 of IOI cases) was Io per cent for the entire period of hospital management. This compares favourably with 12 per cent mortality in the first 2 weeks for such patients in Ontario in 1969-70 (Botterell et al., 1975). Those selected for the anterior operation had a management mortality of $2 \cdot 7$ per cent.

\section{Conclusions}

The records of IOI consecutive cases of cervical spinal injury have been reviewed with emphasis on 74 patients treated by early anterior cervical operations. 
The surgical goals of providing bony alignment, stability, comfort, protection of the neural elements and early mobilisation have been achieved. The low management mortality for those so treated and the negligible continuing morbidity attributable to the procedures are acceptable. Proponents of other methods insist that in the long term, non-operative management produces equally satisfactory results, but the more prolonged confinement to bed and the retention of skull callipers for many weeks lead to complications at least as numerous and dangerous as those reported in this series. Economy of time and bed utilisation are both promoted by early stabilisation of the spine. The favourable overall results are made possible by a team approach in rehabilitation. The effectiveness of the members of the team is enhanced by safe early mobilisation of the patient.

\section{RÉSUMÉ}

Les résultats de IOI cas consécutifs de lésions de la colonne cervicale ont été étudiés, en insistant sur soixante-quatorze malades traités par opérations cervicales antérieures à un stade précoce. On a atteint les objectifs chirurgicaux consistant à donner alignement osseux, stabilité, confort, protection des éléments du système nerveux et mobilisation précoce. Le faible taux de mortalité des patients ainsi traités et les états maladifs ultérieurs négligeables pouvant être attribués à la méthode utilisée sont acceptables. Les partisans d'autres méthodes insistent sur le fait qu'un traitement non-opératoire à long terme donne des résultats aussi satisfaisants, mais le séjour plus prolongé au lit et le port d'attelles crâniennes pendant plusieurs semaines créent des complications au moins aussi nombreuses et dangereuses que celles mentionnées dans cette série. Un gain en termes de temps et d'occupation du lit est favorisé par une stabilisation précoce de la colonne vertébrale. Les résultats positifs globaux sont rendus possibles par le travail en équipe au cours de la réadaptation. L'efficacité des membres de l'équipe est rehaussée par une mobilisation précoce et sûre du malade.

\section{ZUSAMMENFASSUNG}

79 von IOI Fällen mit traumatischen Halsmarkverletzungen hatten frühezeitige anteriore Zervikaloperationen. Die chirurgischen Ziele, Knochenangleichung, Stabilität, Komfort, Protektion der neuralen Elemente, wurden erzielt. Die geringe Mortalität und kontinuierliche Morbidität bei diesem Verfahren sind akzeptierbar. Befürworter anderer Methoden bestehen darauf, dass nicht-operative Behandlung ergeben auf lange Sicht hin die gleichen zufriedenstellende Resultate, aber die längere Bettbehandlung und die Retention des Schädelzugs mit Kalipers für viele Wochen führt mindestens zu zahlreichen und gefährlichen Komplikationen wie sie in dieser Serie berichtet wurden. Oekonomie von Zeit und Betten sind der Vorteil von frühzeitigen Stabilisierung der Wirbelsäule. Die günstigen Resultate sind ermöglicht durch Teamarbeit in Rehabilitation.

\section{REFERENCES}

Beatson, T. S. (1963). Fractures and dislocations of the cervical spine. F. Bone foint Surg. 45B, 2I-35.

Botterell, E. H., Jousse, A. T., Kraus, A. S., Thompson, M. G., Wynne-Jones, M. \& GEISLER, W. O. (1975). A model for the future care of acute spinal cord injuries. Ann. R. Coll. Phys. Surg. Canada, 8, 193-218.

Braakman, R. \& Penning, L. (1973). Mechanisms of injury to the cervical cord. Paraplegia, 10, 314-320.

BURKE, D. C. \& BERRYMAN, D. (I97I). The place of closed manipulation in the management of flexion-rotation dislocations of the cervical spine. F. Bone foint Surg. 53B, I65-I82.

Cheshire, D. J. E. (1970). The stability of the cervical spine following the conservative treatment of fractures and fracture-dislocations. Paraplegia, 7, 193-203.

Clawson, D. K. et al. (197I). Early anterior fusion for cervical spine injury. F.A.M.A. 2!5, 2 I I3-2I I4 (letter to Editor). 
Cloward, R. B. (I96I). Treatment of acute fractures and fracture-dislocations of the cervical spine by vertebral body fusion. f. Neurosurg. 18, $201-209$.

Drake, C. G. (1962). Cervical spinal cord injury. F. Neurosurg. 19, 487-494.

Evans, D. K. (I96I). Reduction of cervical dislocation. F. Bone foint Surg. 43B, 552-555.

GutTMANN, L. (1965). Initial treatment of traumatic paraplegia and tetraplegia. In Spinal Injuries Symposium, Morrison and Gibb Ltd., Edinburgh.

Guttmann, L. (1976). Spinal Cord Injuries and Comprehensive Management and Research. Blackwell, Oxford, 2nd edition.

HaRdY, A. G. (1976). Survival periods in traumatic tetraplegia. Paraplegia, 14, 4I-46.

HolDswORTH, F. W. (1963). Fractures, dislocations and fracture-dislocations of the spine. F. Bone foint Surg. 45B, 6-20.

JACOBS, B. (I975). Cervical fractures and dislocations, C3-7, Clin. Orthopaedics and Related Research, 109, 18-32.

KessLeR, L. A. (I973). Delayed traumatic dislocation of the cervical spine. F.A.M.A. 224, I24-I 25 .

NiEminen, R. (I973). Fractures of spinous processes of the lower cervical spine. Ann. Chir, Gynaecol. Fenn, 62, 328-333.

NiEMINEN, R. (I974). Fractures of the articular processes of the lower cervical spine. Ann. Chir, Gynaecol. Fenn, 63, 204-2 I I.

Norrell, H. \& Wilson, C. B. (I970). Early anterior fusion for injuries of the cervical portion of the spine. F.A.M.A. 214, 525-530.

RANSOHOFF, J. R. \& SADIK, A. R. (I972). Spinal cord injury: current status and recent advances. Surg. Ann. 4, 9I-IoI.

RAYNOR, R. B. (I968). Severe injuries of the cervical spine treated by early anterior interbody fusion and ambulation. F. Neurosurg. 20, 3I I-3I6.

Rogers, W. A. (I957). Fractures and dislocations of the cervical spine. F. Bone foint Surg. 39A, 34I-376.

SCHNEIDER, R. C. (I957). Cervical traction, with evaluation of methods and treatment of complications. Surg. Gyn. and Obst. 104, 52 I-530.

STAUFFER, E. S. \& KAUFER, H. (1975). Fractures and dislocations of the spine. In Fractures (Vol. 2), ed. by C. A. Rockwood and D. P. Green. Lippincott, Philadelphia.

VERBIEST, H. (I973). Anterolateral operations for fractures or dislocations of the cervical spine due to injuries or previous surgical interventions. Clin. Neurosurg. 20, 334-366.

\section{General Discussion}

DR A. HARDY (G.B.). I was particularly interested in the total period of care and what I would like to ask you is, does your 93 days in rehabilitation include the total successful rehabilitation of the bladder?

DR HORSEY. I would say in the majority of cases, yes. In the Neurosurgical Unit under the direction of the Rehabilitation Service, the bladder care is started, actually by the members of the neurosurgical floor using intermittent catheterisation and carried on usually to the point of discharge when they are quite capable of looking after the bladder.

DR Young (Chairman). I have one question on the chap that had a dislocation and subsequently died. I thought I detected just a little separation between the vertebrae there, how much weight did you have on him?

DR HORSEY. That was at $32 \mathrm{lb}$ which is marginally over I think what most of us would accept. In this particular case, this is the result not of my work but another surgeon; I thought at the time that perhaps excessive traction was the cause of it.

DR Young. I think this does concern us all when we get up into the higher weights that we do cause distraction and tension on the cord.

DR HORSEY. The cord tolerates pull very poorly.

Dr A. KEY (S.A.). May I ask you what type of cervical bracing you feel is adequate I3 days after anterior fusion?

DR HORSEY. We usually use a Forrester type of four-poster brace which I don't really think is the best in the world, and that's why I like to see a good internal fixation. The halo traction which we're beginning to use now or halo cast immobilisation, I think we'll probably use more in the future. Some of these may be as well handled without internal 
fixation. I would think that if we could get a form of external fixation which allows us to mobilise the patient, we may do without the internal fixation or some of our operations used currently.

DR KEY. Are you happy to have no external bracing at all after your fusion?

DR HorSEY. Not in these. If a segment's loose it will slip unless you do something externally as well as internally I think. The risk is too high.

MR P. HARRIs. Could I ask you Bill, if you feel that redislocation may occur in patients who have had a full dislocation. I should like to ask this to you and also to others with patients who have had full dislocations; have any people seen re-dislocation occurring after any interval of time after reduction has been achieved.

DR HORSEY. I've seen it in the form of a gradual slip rather than a second injury. The segment will dislocate, subluxate rather. I've never seen facets, which have been replaced, jump again. 